\title{
Review \\ Renewable Energy Status in Azerbaijan: Solar and Wind Potentials for Future Development
}

\author{
Feyruz Mustafayev *, Przemyslaw Kulawczuk and Christian Orobello
}

\section{check for}

updates

Citation: Mustafayev, F.;

Kulawczuk, P.; Orobello, C.

Renewable Energy Status in Azerbaijan: Solar and Wind Potentials for Future Development Energies 2022, 15, 401. https:// doi.org/10.3390/en15020401

Academic Editors: Sonia Leva, Emanuele Ogliari,

Alessandro Niccolai

and Surender Reddy Salkuti

Received: 7 December 2021

Accepted: 29 December 2021

Published: 6 January 2022

Publisher's Note: MDPI stays neutral with regard to jurisdictional claims in published maps and institutional affiliations.

Copyright: (C) 2022 by the authors. Licensee MDPI, Basel, Switzerland. This article is an open access article distributed under the terms and conditions of the Creative Commons Attribution (CC BY) license (https:// creativecommons.org/licenses/by/ $4.0 /)$.
Faculty of Economics, University of Gdansk, Armii Krajowej 119, 81-824 Sopot, Poland; przemyslaw.kulawczuk@ug.edu.pl (P.K.); christian.orobello@ug.edu.pl (C.O.)

* Correspondence: f.mustafayev.438@studms.ug.edu.pl

\begin{abstract}
Azerbaijan has a well-developed hydrocarbon industry backed with abundant domestic resources. Oil and gas have played a crucial role in the economic revival of the country since independence was regained back in 1991. The legal foundation of the transition to carbon-zero energy generation was laid in the 1990s with a number of acts mentioning the importance of the shift. The government has an ambitious plan to improve the situation, though an action plan with targeted renewables share in production and consumption is still to be prepared. This study, based on systematic review methodology for qualitative research, analyzes the potential of renewables in Azerbaijan with a focus on solar and wind power, discusses the deficiencies hindering the development of the renewables industry, and develops recommendations on applicable actions to improve the situation in this regard. It also includes legislative acts of the Republic concerning renewable energy. The main objective of the study is to explore renewable energy potentials and assess the readiness of the country to make a shift towards green energy. The findings of the article demonstrate enough potential to increase the share of renewables. The potential, however, is obscured with a relatively less solid legal framework and a lack of expertise in the industry.
\end{abstract}

Keywords: Azerbaijan; renewable energy; solar power; wind power

\section{Introduction}

Renewable energy is no longer an unusual source but is an inevitable transformation path that has become a focal point for almost all countries around the world. The advantages of renewable sources over conventional energy sources have been debated and proved in many platforms up to now. The major pros of hydrocarbons-lower price-are vanishing at a high pace with the technological development pushing green energy prices lower. As per the latest figures, high-efficiency solar and wind-based generation undercuts even the cheapest fossil-based generation plants in terms of levelized cost of electricity (LCOE) in 2020 [1]. According to the International Renewable Energy Agency (IRENA), wind and solar installation costs have seen up to an $81 \%$ decrease during 2010-2020, while the LCOE for those sources became cheaper by up to $85 \%$ (see Table 1 ).

Meanwhile, the share of renewables in global energy generation increased to $29 \%$ in 2020, a $2 \%$ increase in comparison to 2019 [2].

Azerbaijan's renewable energy journey is relatively new as its abundant fossil fuel reserves have long been serving as the main raw material for energy generation. Low production price, high energy security in terms of resource supply, and huge capital investments in the oil and gas industry have resulted in a long-standing focus on hydrocarbons as the sole resource to generate energy. Thus, the momentum of transition to carbon-zero energy generation in Azerbaijan is challenged by a lack of solid legal framework, no expertise on the matter, and low private and public capital investments. Since its independence, the shift to renewables has been obscured by the comfort of the immense domestic hydrocarbon resources of Azerbaijan. Nonetheless, understanding the scarcity of resources in lieu of 
decreasing extraction levels makes it clear that long-term reliance on hydrocarbons as the sole option to generate energy is unsustainable. The BP report presented figures showing the reserves-to-production $(\mathrm{R} / \mathrm{P})$ ratio of oil in Azerbaijan is around 24 years. The same indicator for natural gas is around 117 years though [3].

Table 1. Total installed costs and LCOE trends by technology, 2010 and 2020 [2].

\begin{tabular}{ccccccc}
\hline & \multicolumn{3}{c}{ Total Installed Costs } & \multicolumn{2}{c}{ Levelized Cost of Electricity } \\
\cline { 2 - 7 } & \multicolumn{3}{c}{$\mathbf{( 2 0 2 0 \text { USD/kW) }}$} & \multicolumn{2}{c}{$\mathbf{( 2 0 2 0 \text { USD/kWh) }}$} \\
\cline { 2 - 7 } & $\mathbf{2 0 1 0}$ & $\mathbf{2 0 2 0}$ & $\begin{array}{c}\text { Percent } \\
\text { Change }\end{array}$ & $\mathbf{2 0 1 0}$ & $\mathbf{2 0 2 0}$ & $\begin{array}{c}\text { Percent } \\
\text { Change }\end{array}$ \\
\hline Solar PV & 4731 & 883 & $-81 \%$ & 0.381 & 0.057 & $-85 \%$ \\
\hline Onshore wind & 1971 & 1355 & $-31 \%$ & 0.089 & 0.039 & $-56 \%$ \\
\hline Offshore wind & 4706 & 3185 & $-32 \%$ & 0.162 & 0.084 & $-48 \%$ \\
\hline
\end{tabular}

The shift to renewables accelerated during the last two decades with a number of renewable projects implemented and announced to be accomplished in the near future. Limited expertise in the industry, insufficient legal framework, and low public awareness on the topic are some of the challenges the country is facing. The major document to boost the green energy program, the State Program on the Use of Alternative and Renewable Energy Sources in the Republic of Azerbaijan, was adopted in 2004 with a clear-cut action plan defining relevant state entities responsible for implementation and setting timeframes for each of them [4]. The 2004 Program specifically listed wind, solar, hydro, biomass, and geothermal power accentuating existing privilege in terms of the abundance of mentioned resources. Nonetheless, no specific measures to attract private capital, liberate the energy market, incentivize ownership of green resources as the main source of energy generation were introduced.

\section{Materials and Methods}

The rationale of this review is to make the assessment of the readiness of the analyzed country to introduce energy policy shift towards renewable energy with special emphasis placed on solar and wind energy. The requirements for systematic reviews are shaped for qualitative and quantitative data with a special stress placed on the assessment of quantitative results which typically justify the final conclusion of the review in the environment of the large number of available statistical data. Here, due to qualitative character of this study and relatively limited number of reports (56 analyzed positions), we used a simplified methodology adjusted to the review needs and relevance of the collected materials to the analyzed topic. The main objective of the article is to explore the potential of renewable energy source development in Azerbaijan-with the main focus on solar and wind power over the next twenty years. Our hypothesis is that Azerbaijan has unused development potential in this area. The paper will analyze opportunities for development considering the existing potential, discuss the legal framework, and suggest mechanisms to boost the renewable energy industry (REI).

The data collected for the review were grouped in the following dimensions: (1) energy infrastructure, production and consumption in Azerbaijan; (2) potential of renewable energy in Azerbaijan; (3) legal framework regulating renewables and incentivization; (4) conclusions and recommendations. The search strategy was focused on assuring maximum relevance of the collected data to the review topic and its dimensions. The search strategy was also aimed at providing updates to the present situation. The selection criteria preferred the first resort sources (e.g., created by public bodies or international organization), scientific materials created with participation of local authors, and other scientific materials which revealed facts important for the study. We excluded materials providing general information or brief insights and all confusing materials which contained all the keywords but concerned other areas. The data collection process was done by three authors 
who divided duties into local sources, sources from public bodies and international organizations and scientific publications publicized in English, Russian or Azerbaijani languages. The results were cross-checked by partner authors.

Data points were sought for the following outcomes: diagnosis of the present stage of renewable energy development in Azerbaijan, the list and justification of existing potentials for renewable energy developments, assessment of the legal framework to facilitate the renewable energy development, recognition of policy gaps and analysis on how to fix them. We reduced the number of observable variables to those which had critical importance for the research. It means that there were several issues which were unclear during the research, such as the detailed strategy of the change towards renewable energy and legislation framework final outline. However, those issues were addressed by authors in the form of propositions and recommendations. We also assessed the risk of bias in the used studies by specifying the distance of the analyses and proposed tools to the existing energy policy. It revealed that the energy policy is in a stage of change and any definite final solutions were not completed. On the other side, an update of Azerbaijan's energy policy requires new insights which this publication will reveal.

We specified for each outcome the effect measure including: (1) diagnosis-statement of the up-to-date development of renewable energy in Azerbaijan, (2) analysis of potentialsqualitative assessment of potentials for renewable energy, (3) legal framework assessmentstatement on the quality of legal framework, (4) policy recommendations aimed at elimination of energy policy gaps-gap elimination opportunities. Syntheses of the reviews were placed at the end of each point and were based on summarizing the key observations. We used all relevant materials and based our synthetic conclusions on all eligible reports.

We made a reporting biases assessment taking into consideration that they arise when the dissemination of research findings is influenced by the nature and direction of results [5]. Our review considered mostly the projections of future policies and, in many areas, such projections are shaped by a wishful thinking approach which indicates what should be done in the absence of confronting it with existing potentials. Our goal in this study was to eliminate all provisions of projections which were not backed by evidenced potentials. Besides, we also checked whether all envisaged investments in REI are possible to be realized (e.g., the space provided for them was used for a different investment). Typically, the certainty assessment is done on the basis of factors that reduce the risk of bias, inconsistency, indirectness, imprecision, and reporting bias [6]. Due to the relatively low number of reports and data and controlling all the above-mentioned risk factors, we performed a certainty assessment by assessing the quality of the collected evidence to the planned outcomes.

Overall, we assessed the evidences as acceptable and of satisfactory quality but not necessarily at the highest possible level. All selected studies were cited in the publication and study characteristics were only described when research results were discussed. Authors skipped characterizing studies when only facts and field information were cited. We briefly described pioneer studies undertaken for the first time. We decided to include in our research only the studies with low risk of bias and excluded all studies with substantial risk. A table with individual risks indications was not necessary. The authors presented results of individual studies included in the review using a score from 1 to 5 . The research team did not include any evidence which would have limitations important for the review. Due to the qualitative nature of the data included in the research and their focus on future projections, the review process methodology was using the fundamental elements of the systematic review methodology characteristic for qualitative studies and omitted, e.g., statistical elements which are characteristic for quantitative studies. Due to the thematic area (non-medical), the registration and protocol were not applied. The authors did not receive any support for the review, declare no competing interests, the rejected reports were removed.

As mentioned before, the existing literature assessing the renewable potential of Azerbaijan is relatively weak. A handful of studies have been carried out in this direction, mainly 
by the National Academy of Sciences and a few scholars, such as Nijat Imamverdiyev, Rovshan Karimov, Rustam Shafagatov, and others. The only publicly available data collection on wind potential was carried out by Nijat Imamverdiyev in his 2004 study [7]. A similar dataset on solar potential is not available. Thus, the scarcity of reliable and valid data remains the main limitation of this study.

The world hosts nearly two hundred countries at the moment with dozens of them located approximately at the same latitude as Azerbaijan. Similarly, numerous countries have close to Azerbaijan weather conditions, including sunlight and wind resources for production purposes. Trying to look for the countries with the best REI, this study will focus on the ones with not only close to Azerbaijan climate and geographical conditions, which directly affects the amount of sunlight and has an impact on the wind potential, but also considers factors such as population and territory size. Though deviation, especially in relation to the latest two indicators are present. Nonetheless, the whole purpose of this analysis lies behind defining the legal framework approach in support of renewable resources. Thus, the geographical location remains the major factor for selecting the countries, along with achieved successes in the penetrating the green energy into utilization. The reason for considering territory size and population is to avoid a possible level of analysis problem. In the below analysis, the following countries-Austria, Portugal, Greece, Croatia will be taken into consideration (see Table 2).

Table 2. Best practice countries selected for this study [8-10].

\begin{tabular}{ccccc}
\hline & $\begin{array}{c}\text { Geographical Location } \\
\text { (Mid Point) }\end{array}$ & Territory Size $\mathbf{( k m}^{\mathbf{2}}$ ) & Population (Million) & $\begin{array}{c}\text { Installed Renewable } \\
\text { Capacity, 2019, MW }\end{array}$ \\
\hline Azerbaijan & $40.1431^{\circ} \mathrm{N}, 47.5769^{\circ} \mathrm{E}$ & 86,600 & 10.0 & 1279 \\
\hline Austria & $47.5162^{\circ} \mathrm{N}, 14.5501^{\circ} \mathrm{E}$ & 83,879 & 8.58 & 20,628 \\
\hline Portugal & $39.3999^{\circ} \mathrm{N}, 8.2245^{\circ} \mathrm{W}$ & 92,226 & 10.0 & 14,068 \\
\hline Greece & $39.0742^{\circ} \mathrm{N}, 21.8243^{\circ} \mathrm{E}$ & 131,957 & 10.7 & 9805 \\
\hline Croatia & $45.1000^{\circ} \mathrm{N}, 15.2000^{\circ} \mathrm{E}$ & 56,594 & 4.0 & 3005 \\
\hline
\end{tabular}

China, the United States, Brazil, Germany, and India are in the top five in terms of total installed renewable capacity [10]. Germany, United Kingdom, Sweden, Spain, and Italy lead the ranking in the list of countries with the highest share of renewables in energy utilization [11].

Azerbaijan has begun to explore renewable energy opportunities to increase its energy security, utilize hydrocarbon resources differently, diversify the energy market. Besides, due the expectation that hydrocarbons will become more scarce in the future, such an orientation can free some hydrocarbon resources used for energy production in Azerbaijan to utilize them in more processed ways which can assure an increased value than using them for energy production. The following paragraphs of the article deal with the current energy infrastructure, solar and wind potential, legal framework, and incentivization. The article will be concluded with the main recommendations that could be put in place to speed up the transformation process and how to utilize opportunities which will arise with freeing hydrocarbons used for energy production.

\section{Energy Infrastructure, Production and Consumption in Azerbaijan}

Oil and gas have historically been the main commodity in Azerbaijan to produce income, generate energy, open workplaces, and develop the economy. The first industrial oil well was drilled in Bibi-Heybat, Azerbaijan in 1848. Local sources claim it was the firstever industrial well [12,13]. The next fully industrial well in Azerbaijan was built in 1871 in Balakhani. As of 1872, Azerbaijan was already extracting more than a million poods (pood is a unit of mass measurement equivalent to $16.38 \mathrm{~kg}$; Yakovlev, Development of Wrought Iron Production, Metallurgist press, 1957) of oil and reached a hallmark of 500 million poods in 1899 [14]. The historical expertise and loyalty to conventional resources, which 
became the main revenue generator in the late 1800s, transformed into a developed industry after the 1960s. All these combined with a relatively low level of development of REI, paved the path for fossils to become the cornerstone of the energy infrastructure in Azerbaijan.

Thus, the current energy infrastructure of Azerbaijan is heavily dependent on fossils, as $5550.5 \mathrm{MW}$ out of 6721.5 total installed capacity relies on hydrocarbons to produce electricity. Hydropower plants are the second major contributor to the overall generation with an installed capacity of 1.171 MW (for the major power generating plants see Table 3).

Table 3. Power generating plants in Azerbaijan [15].

\begin{tabular}{|c|c|c|}
\hline Thermal Power Plants (TPP) & Hydro Power Plants (HPP) & $\begin{array}{l}\text { Small Hydro Power Plants } \\
\text { (SHPP) }\end{array}$ \\
\hline Azerbaijan TPP—2400 MW & Mingachevir HPP—402 MW & Gulabird SHPP_-7.5 MW \\
\hline Janub PP—780 MW & Shamkir HPP—380 MW & Oghuz SHPP 1,2 \& 3-3.6 MW \\
\hline Sumgait PP-525 MW & Yenikend HPP_-150 MW & Goychay SHPP-3.1 MW \\
\hline Shimal 1 and 2 PPs-800 MW & Fuzuli HPP—25 MW & Ismayıllı-1 SHPP—1.6 MW \\
\hline Sangachal PP-300 MW & Takhtakorpu HPP—25 MW & Ismay1ll1-2 SHPP-1.6 MW \\
\hline Baku TEC-107 MW & Shamkirchay HPP_-25 MW & Balaken-1 SHPP-1.5 MW \\
\hline Baku PP-105 MW & Varvara HPP $-16.5 \mathrm{MW}$ & Gusar SHPP—1 MW \\
\hline Shahdagh PP-105 MW & Araz $\mathrm{HPP} \_44 \mathrm{MW}$ & Vaykhir HPP—5 MW \\
\hline Astara PP-87 MW & Bilev HPP—22 MW & \\
\hline Shaki PP-87 MW & Arpachay 1, Arpachay 2-21.9 MW & \\
\hline Khachmaz PP_87 MW & Ordubad HPP—36 MW & \\
\hline \multicolumn{3}{|l|}{ Nakhchivan PP—87 MW } \\
\hline Nakhchivan gas-turbine $\mathrm{PP}-64 \mathrm{MW}$ & & \\
\hline
\end{tabular}

Not surprisingly, fossils remain the major shareholder in electricity production by resource type indicator. Hydrocarbon-based power and thermal power plants generate 22,290 million kWh out of the total of 26,072 million kWh electricity in 2019 (see Figure 1).

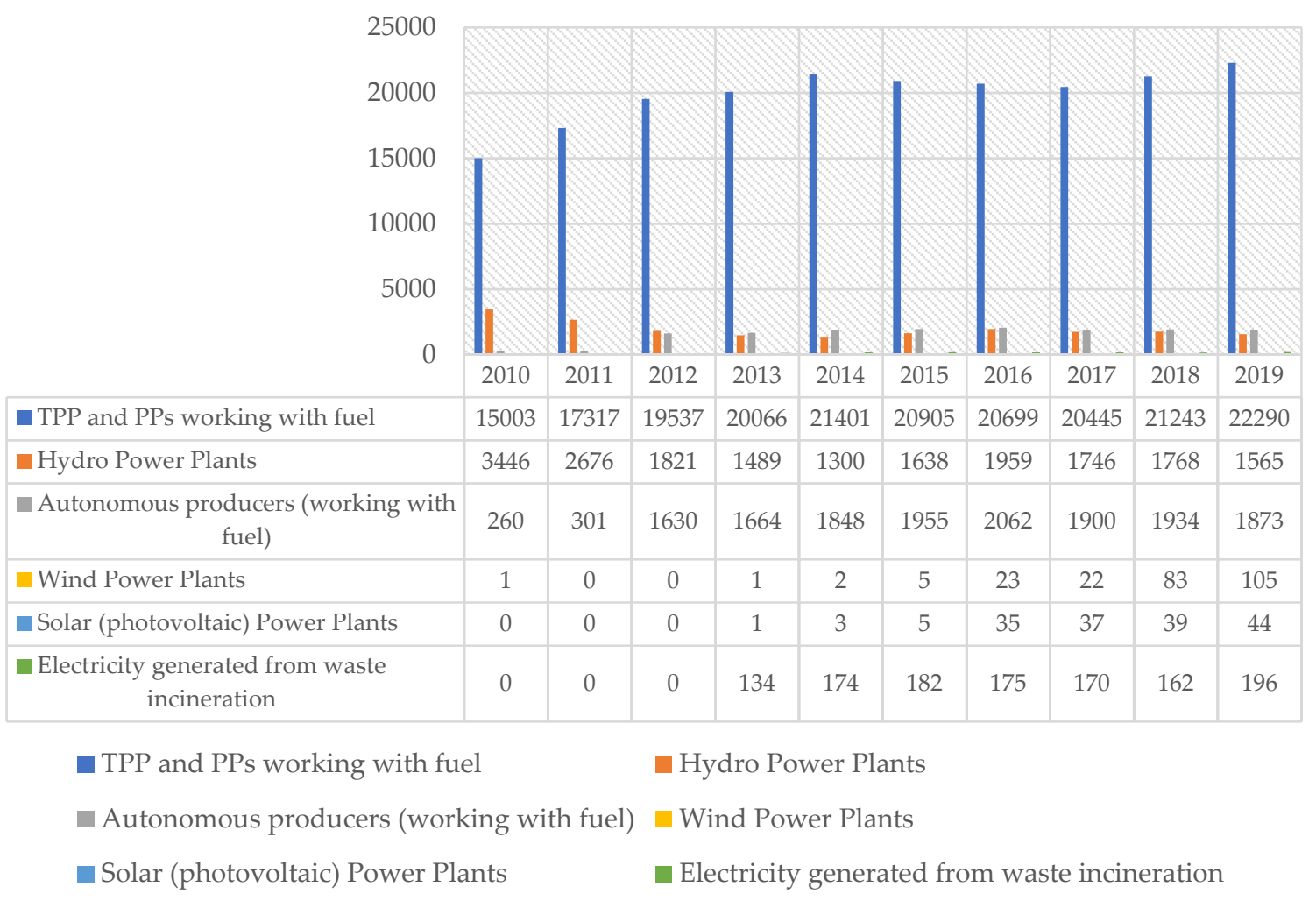

Figure 1. Power generation and types of resources used in Azerbaijan (million kWh) [15]. 
Oil and gas extracted from various spots, but mainly from the Caspian basin, helped not only with power generation, but became the main locomotive of the economy since the "Contract of the Century" was signed in 1994, three years after Azerbaijan declared its independence. Eleven global scale companies from seven countries have signed joint development and production sharing agreement that opened doors for cash flow into the hydrocarbon industry (see Figure 2).

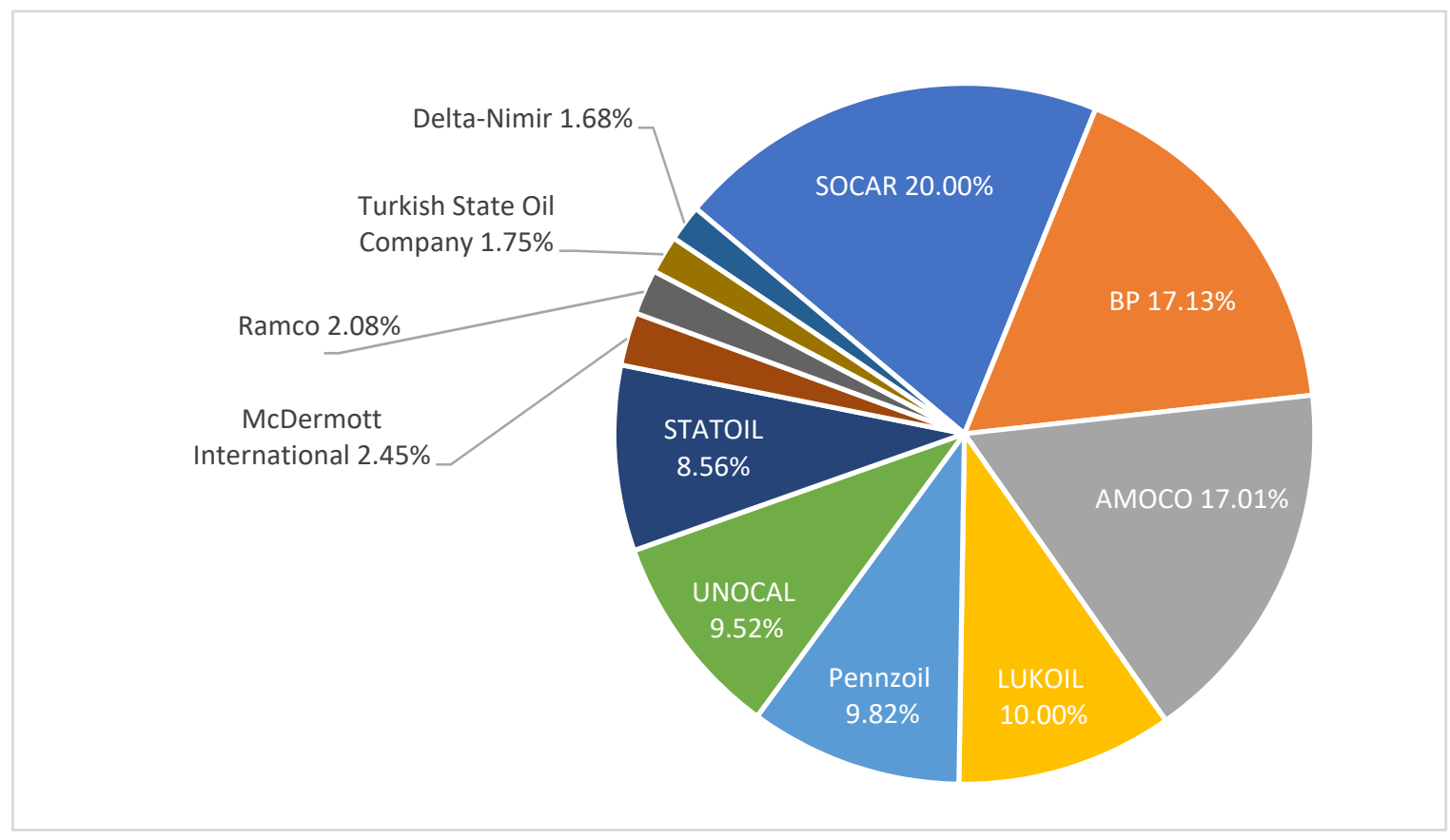

Figure 2. Shares of companies in the Contract of the Century in Azerbaijan (1994) [16].

Soon after revenues from the sales of oil and gas resources started flowing, it became the major contributor to the economy of Azerbaijan. The share of oil- and gas-related income in gross domestic production (GDP) yielded significantly after the Baku-Tbilisi Jeyhan oil pipeline was set for operation in 2005 (see Figure 3).

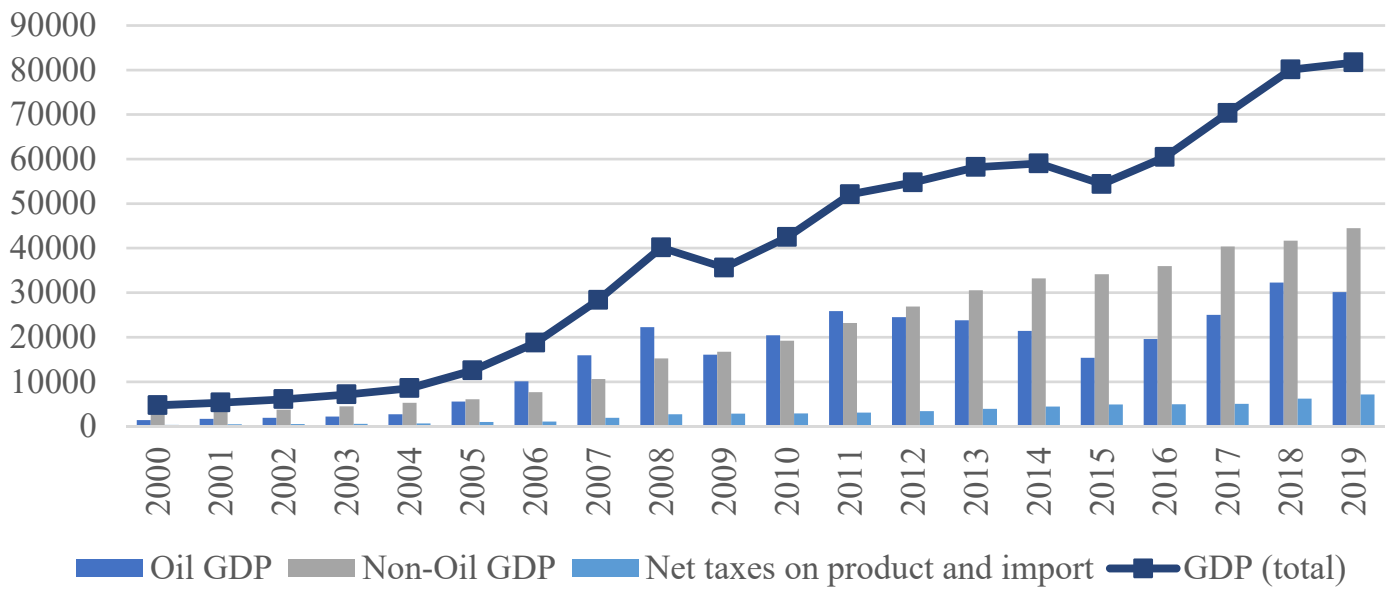

Figure 3. Composition of GDP of Azerbaijan in million AZN [17] (USD 1 equals to AZN 1.7 as of 18 October 2021. Exchange rates are fixed and managed by the Central Bank of Azerbaijan (www.cbar.az, accessed on 18 October 2021). Average inflation rate for 2000-2020 in Azerbaijan constitutes $6.39 \%$ [18]).

The utilization of sunlight and wind as energy generation resources started a decade ago. Though in low capacity, wind and solar farms are not a rarity anymore. The State 
Agency for Alternative and Renewable Energy (SAARE) has implemented and drafted a number of wind and solar farm projects. The 2014 report of the SAARE included information about 12 wind plants with a total installed capacity of $402.94 \mathrm{MW}$ (see Table 4). The 2018 presentation of the Ministry of Energy envisioned the development of 6 wind plants without giving detailed information on the earlier announced wind plants (see Table 5).

Table 4. List of installed and envisaged wind energy plants (WEPs) in Azerbaijan in 2014 [7].

\begin{tabular}{ccc}
\hline Name of the WEP & Output Capacity (MW) & Location \\
\hline Gobustan & 2.7 & Gobustan \\
\hline \multirow{2}{*}{ Shurabad } & 15 & Khizi \\
\cline { 2 - 3 } & 25 & Khizi \\
\cline { 2 - 3 } Pirakushkul & 60 & Pirakushkul 1 \\
\hline Shurabad & 150 & Pirakushkul 2 \\
\hline Sitalchay & 33 & Khizi \\
\hline Khizi & 25 & Khizi \\
\hline Mushfiq & 3.6 & Khizi \\
\hline Pirallahi Wind Park & 9 & Mushfiq settlement \\
\hline New Yashma & 15 & Caspian Sea \\
\hline Ecological Park & 50 & Khizi \\
\hline Clean City & 0.04 & Baku \\
\hline Samukh Agro-Energy Complex & 9.6 & Zira \\
\hline TOTAL & 5 & Samukh \\
\hline
\end{tabular}

Table 5. List of prospective WEPs offered [19].

\begin{tabular}{cc}
\hline Project Title & Capacity (MW) \\
\hline Khizi-1 (Shurabad) & 56.1 \\
\hline Khizi-2 HES & 69.0 \\
\hline Khizi-3 & 135.0 \\
\hline Absheron HES & 55.2 \\
\hline Lokbatan & 26.7 \\
\hline Gobustan HES & 8.0 \\
\hline TOTAL & 350 \\
\hline
\end{tabular}

The total installed solar capacity was $40 \mathrm{MW}$ across 11 plants, as per the Ministry of Energy of Azerbaijan in 2020 [20].

Unfortunately, there is not much publicly available information on solar plants in operation, though the SAARE and the Ministry of Energy claim a total generation capacity of $37 \mathrm{MW}$. One of the SAARE reports enlisted a number of solar projects implemented as of 2020 with a total installed capacity of 50 MW (see Table 6). 
Table 6. List of projected solar plants in Azerbaijan in 2018 [19].

\begin{tabular}{cc}
\hline Project & Capacity (MW) \\
\hline Surakhani & 1.7 \\
\hline Sumgait & 1.8 \\
\hline Pirallahi-1 & 2.2 \\
\hline Pirallahi-2 & 7.2 \\
\hline Samukh-1 & 0.4 \\
\hline Samukh-2 & 7.2 \\
\hline Gobustan HES (solar component) & 5.0 \\
\hline Khizi-2 HES (solar component) & 10.0 \\
\hline Absheron HES (solar component) & 10.0 \\
\hline Siyazan & 4.5 \\
\hline TOTAL & 50 \\
\hline
\end{tabular}

Despite abundant sunlight, much attention is paid to the development of wind electricity production if to analyze the number of envisaged solar projects in comparison to the prospective wind farms announced.

In 2019, the government of Azerbaijan struck a deal with well-established companies to set up solar and wind plants. A solar plant with a total output capacity of $200 \mathrm{MW}$ is agreed to be set up in Azerbaijan jointly with Abu Dhabi Future Energy Company "Masdar". The annual electricity generation capacity of the plant is estimated to be around 410,000 MWh. The estimated cost of the project is USD 120 million. The LCOE of solar electricity generated in the mentioned projects will be approximately equal to USD 0.031 per $\mathrm{kWh}$, as per available information (the calculation is carried out based on the exchange rate provided by the Central Bank of Azerbaijan for 14 August 2021; 1 USD equals 1.7000 AZN (www.cbar.az, accessed on 14 August 2021)). In the same year, the government signed a contract with the "ACWA Power" company of the United Arab Emirates on the construction of a wind energy plant with an output capacity of $240 \mathrm{MW}$. The anticipated yearly electricity output of the project is equal to 1 million MWh. The construction cost is estimated to be around USD 280 million. The LCOE of electricity generated in these plants will approximately equal to USD 0.032 per $\mathrm{kWh}$. The energy market remains monopolized by public entities, although existing legislation allows private generators to become an actor. The main actors in the energy market are listed in Table 7.

Table 7. Key energy market actors.

\begin{tabular}{lll}
\hline & Actors & Roles \\
\hline 1 & Ministry of Energy & $\begin{array}{l}\text { Regulates the market; acts as the main body } \\
\text { responsible to implement the legal acts }\end{array}$ \\
\hline 2 & Azerenerji OJSC & Produces electricity \\
\hline 3 & Azerishiq OJSC & Sells and distributes electricity \\
\hline 4 & SAARE & Responsible for the development of the REI \\
\hline
\end{tabular}

\section{Own Elaboration}

The transmission grid infrastructure is also under the complete control of public entities. Requirements and necessary licenses to connect to the grid are available in various legal documents. The development of publicly available tools is needed to be put in place to increase awareness of the private generation opportunities.

Summarizing, it can be admitted that the review of relevant reports and publications indicates that the role of renewable energy in Azerbaijan is still placed on the stable low level. The authorities of Azerbaijan undertook several undertakings in wind and solar 
energy, but the main source of renewable energy was up to date hydro energy strongly dependent on the volume of water in rivers. We assess those conclusions as certain and with low-risk bias.

\section{Potential of Renewable Energy in Azerbaijan and Its Integration into the Energy System}

For more than a hundred years, hydropower was the major renewable source of energy in Azerbaijan. The first hydropower plant (HP) was constructed in 1883 in Galakend village in the Gedebey district. That plant was designed to supply electricity to the residents, and also to the industrial infrastructures of the community [21]. In the 1950s, Varvara HP and Mingachevir HP boosted the generation levels marking the next stage of the development for the hydropower industry. Mingachevir HP remains one of the biggest hydropower plants in Azerbaijan to date. Until 2009, when the first $\mathrm{kW}$ of wind electricity was produced, water remained the only source of renewable energy. Below is the Figure 4, demonstrating overall electricity generation and the share of hydropower plants in it.

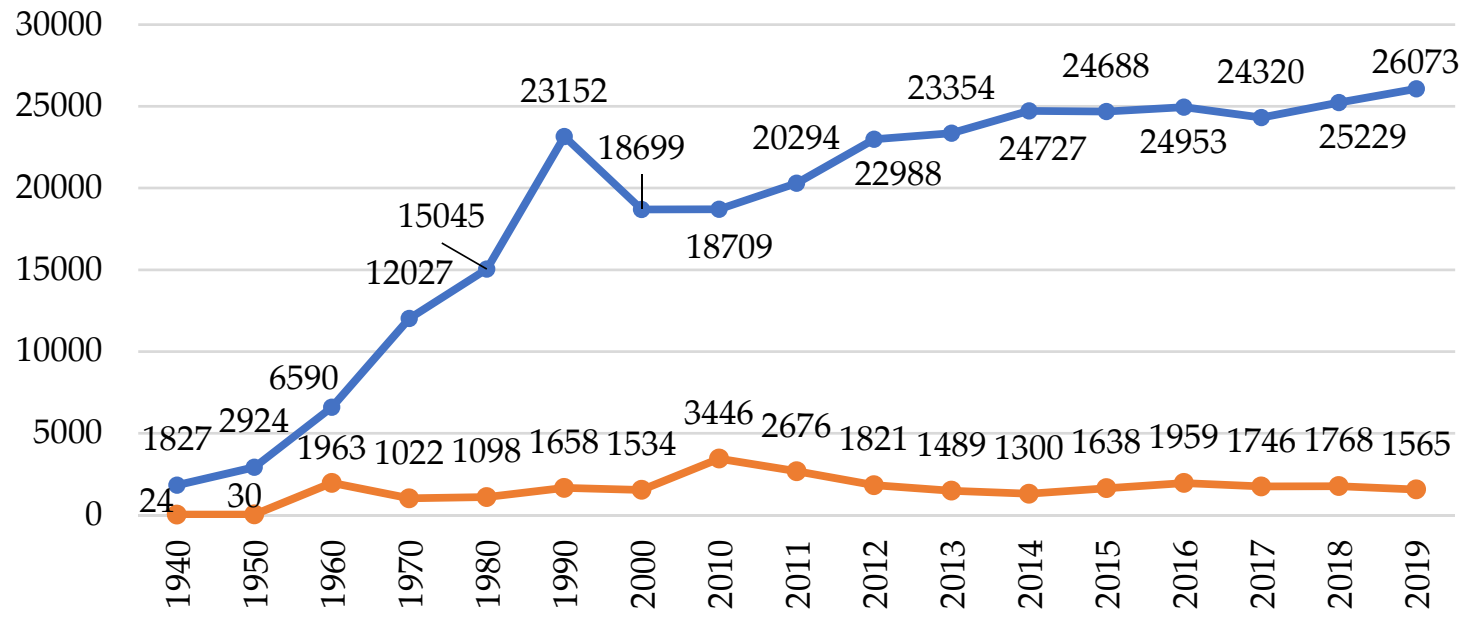

-Total electricity production $\quad-$ Hydropower energy

Figure 4. Total electricity production and share of hydropower energy (million kWh, 1940-2009) [22].

Though Azerbaijan is located in a favorable geographical location to farm solar and wind power, its renewable potential has never been fully studied until recently. In 2002 and 2009, a few studies were conducted by the members of the Azerbaijan National Academy of Sciences to assess the wind energy potential [7]. As of 2019, the Ministry of Energy of Azerbaijan started collecting more data on the renewable potential of the country. The major research in this direction was concluded in 2020 by IRENA who indicated high solar and wind potential in the final report. Table 8 shows the renewable resources potential in Azerbaijan.

Table 8. Renewable resources potential in Azerbaijan (by IRENA) [23].

\begin{tabular}{cc}
\hline Renewables & Technical Capacity, MW \\
\hline Solar & 23,040 \\
\hline Wind & 3000 \\
\hline Bio/Waste & 380 \\
\hline Small Hydropower & 520 \\
\hline Total & 26,940 \\
\hline
\end{tabular}




\subsection{Solar Potential}

Azerbaijan has enough annual sunlight volume to generate significant energy from it. IRENA's assessment of the solar potential of Azerbaijan discovered the 23,000 MW potential [23]. As per governmental records, the amount of solar energy per square meter is somewhere around 1.5-2.0 MWh [24]. The SAARE reports indicate 170 to $260 \mathrm{~W} / \mathrm{m}^{2}$ radiation levels in the country. The World Bank's Global Solar Atlas confirms that the specific photovoltaic power output (SPPO) indicator for Azerbaijan ranges between 3.21-4.48 kWh/kWp (specific photovoltaic power output indicates how much electricity can be produced for every kWp of the module capacity over a course of year [25]). The Direct Normal Irradiation (DNI) and Global Horizontal Irradiation (GHI) indicators are in the range of $2.71-4.84 \mathrm{kWh} / \mathrm{m}^{2}$ and $3.44-4.80 \mathrm{kWh} / \mathrm{m}^{2}$ per day, respectively [26].

The above maps in the Figures 5-7 indicate adequate sunlight to invest in solar farms as alternative energy. Hence, the government has already presented three large-scale potential solar farm projects with a total of $2825 \mathrm{MW}$ installed capacity (see Table 9).

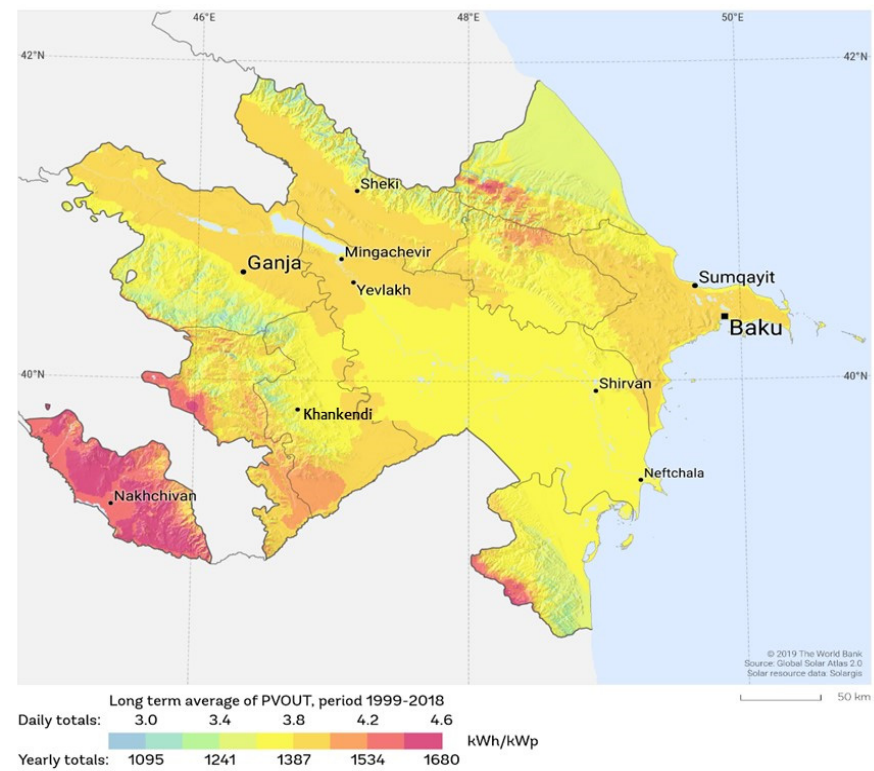

Figure 5. The photovoltaic power potential of Azerbaijan [26].

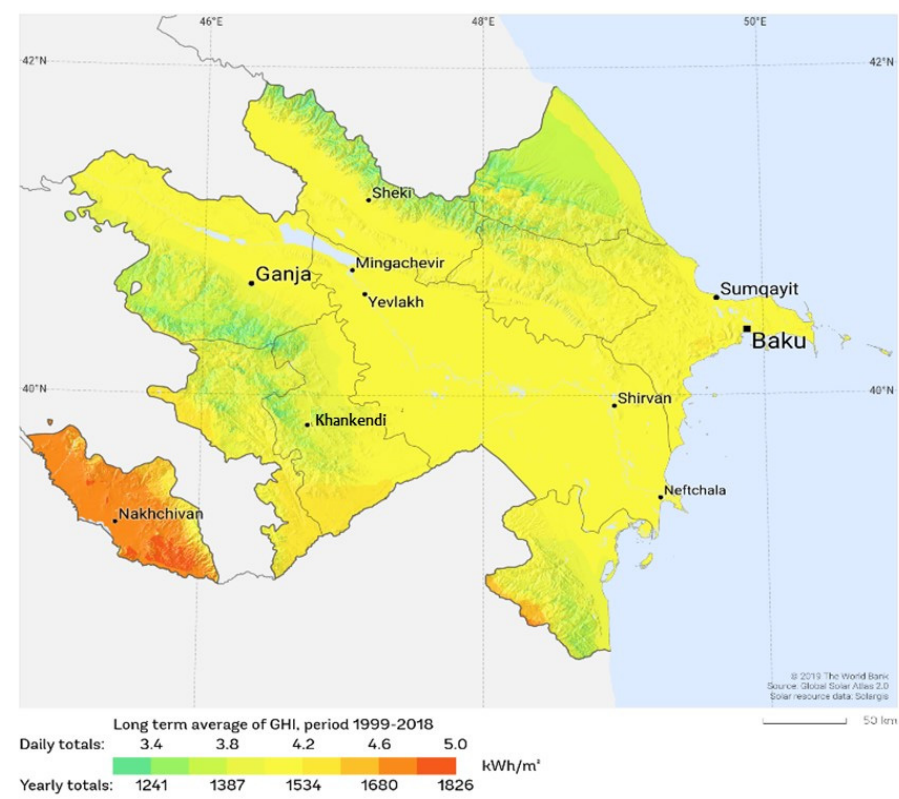

Figure 6. Global Horizontal Irradiation map of Azerbaijan [26]. 


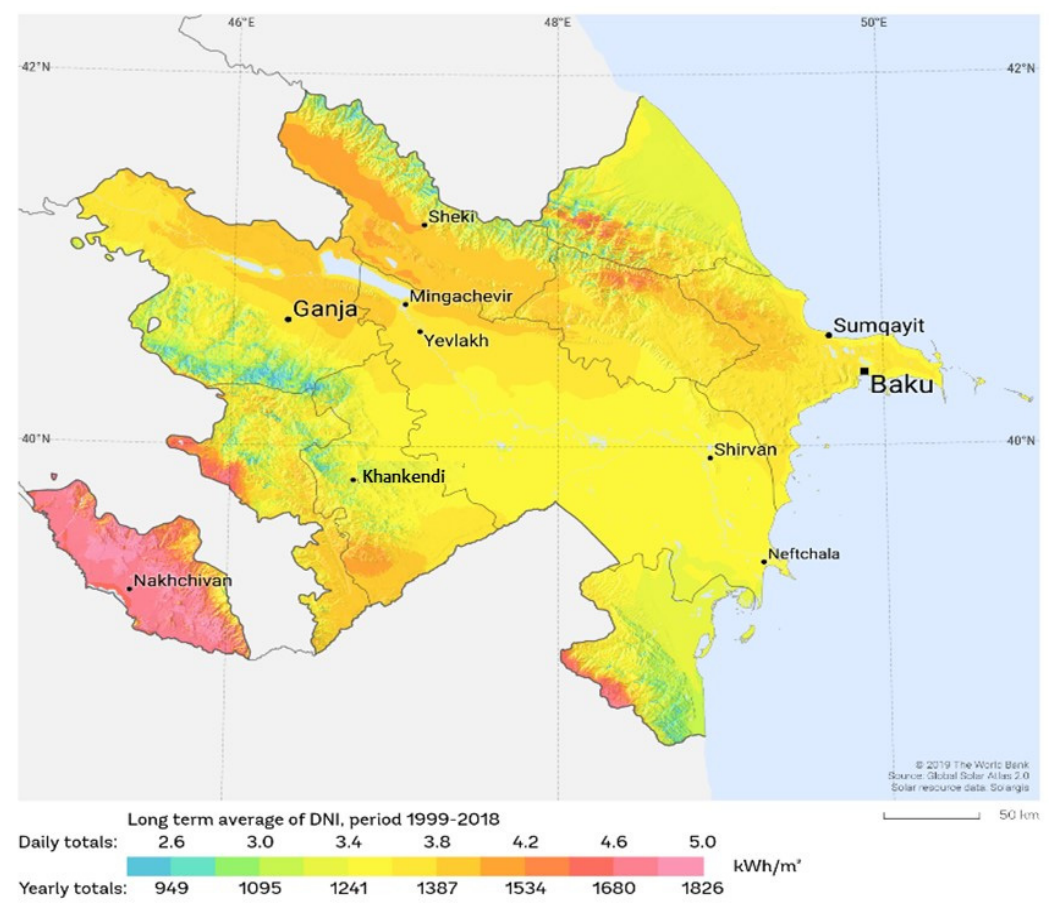

Figure 7. Direct Normal Irradiation map of Azerbaijan [26].

Table 9. Prospective solar plant projects presented by the Ministry of Energy of Azerbaijan [27].

\begin{tabular}{ccc}
\hline $\begin{array}{c}\text { Project Name and } \\
\text { Location }\end{array}$ & $\begin{array}{c}\text { Planned Output } \\
\text { Capacity }\end{array}$ & Estimated Generation \\
\hline Project 1-2200 hectares in Hajigabul district & $1100 \mathrm{MW}(4.4$ million panels $\times 250 \mathrm{~W})$ & $1.46 \mathrm{million} \mathrm{MWh} /$ year \\
\hline Project 2-850 hectares in Absheron peninsula & $425 \mathrm{MW}(1.7$ million panels $\times 250 \mathrm{~W})$ & $579,000 \mathrm{MWh} /$ year \\
\hline Project 3-2600 hectares next to Alat settlement & $1300 \mathrm{MW}(5.4$ million panels $\times 250 \mathrm{~W})$ & $1.725 \mathrm{million} \mathrm{MWh} / \mathrm{year}$ \\
\hline
\end{tabular}

Calculation estimations conducted by Feyruz Mustafayev have revealed other potential projects that could be implemented in the Nakhichevan Autonomous Republic, where solar indicators are even higher in comparison with the rest of the country (see Table 10) [28].

Table 10. Potential solar plants in the Nakhichevan Autonomous Republic.

\begin{tabular}{ccl}
\hline Project Name & $\begin{array}{c}\text { Estimated Installed } \\
\text { Capacity }\end{array}$ & Estimated Generation \\
\hline Area 1-794 ha & $372.5 \mathrm{MW}(1.49$ million panels $\times 250 \mathrm{~W})$ & $385,000 \mathrm{MWh} /$ year \\
\hline Area 2-514 ha & $240 \mathrm{MW}(963,000$ panels $\times 250 \mathrm{~W})$ & $250,000 \mathrm{MWh} /$ year \\
\hline Area 3-416 ha & $195 \mathrm{MW}(780,000$ panels $\times 250 \mathrm{~W})$ & $202,000 \mathrm{MWh} /$ year \\
\hline
\end{tabular}

Source: Feyruz Mustafayev, Design of Solar Plants and Wind Farms Locations in Azerbaijan in the Perspective of Twenty Years, Working paper, 2021 [28].

Industrial-sized plants require huge upfront investments and carry enormous techni$\mathrm{cal} /$ administrative burdens and business risks. Nonetheless, large-scale solar plants are not the only option for sunlight farming. The specifications of photovoltaic panels and technological developments open doors to develop private small- or community-scale generation sites. Besides, the opportunity of roof-top installation creates significantly high generation potential without sacrificing large territories under plants. According to the Ministry of Energy and various foreign open sources, daily sunny hours in Azerbaijan average at $7-8 \mathrm{~h}$ (average number is derived from available documents of the Ministry of Energy of Azerbaijan, www.worlddata.info, and www.weather-and-climate.com websites. All sources were 
accessed on 10 October 2021). Considering $1.6 \mathrm{~m}^{2} 250 \mathrm{~W}$ monocrystalline photovoltaic panels with a $20 \%$ efficiency rate (the most widely used and accessible panels [29]), the output of $0.375 \mathrm{kWh} /$ day or $11.25 \mathrm{kWh} /$ month can be obtained from a single panel installed privately (the calculation is made based on the following formula: $\mathrm{E}=(\mathrm{H} \times \mathrm{W} \times 20) / 100)$. Obviously, the lack of a number of factors, such as tilt degree, air temperature, shade, precipitation, etc., decreases the validity of the calculations. Nonetheless, it puts the perspective of private utilization potential on the surface. Observing the Figure 7, it must be noted that the areas with the highest solar potentials are located far from the economic centers of Azerbaijan (such as Baku), which will create a challenge for the transmission of this energy to the center. On the other side, providing autonomous renewable energy system for the Nakhichevan Autonomous Republic can reduce the present tension for limited access to energy in this region. The development of solar energy installations in this region would also increase the energy security for the Republic of Azerbaijan.

Summing up, Azerbaijan has notable sunlight energy potential, especially in regions with extraordinary conditions for photovoltaic farms location (Nakhichevan AR) and, therefore, solar energy is the first natural direction of renewable energy development in the country. We assess those findings as significant and with low-risk bias.

\subsection{Wind Potential}

Although the estimated wind potential in Azerbaijan is lower in comparison to the solar potential (see Table 8), many efforts are being put into the development of wind electricity production. The decreasing price of wind electricity farming is another factor stimulating interest in this industry. In 2018, wind electricity generation costs went lower in comparison to conventional generation, as per Forbes [30]. The current generation capacity of WEPs in Azerbaijan is around 66 MW [20].

The IRENA's assessment of the wind potential of Azerbaijan does not include data on annual average wind speed and the number of windy days based on months and different regions. The only available dataset on this indicator was presented in 2014 by Nijat Imamverdiyev in his "Azerbaijan's Wind Energy Potential and its Utilization Perspectives" study (see Table 11). This study, however, provides enough insight for the assessment of investment opportunities in this area in Azerbaijan.

The Absheron peninsula and the surrounding areas have high wind energy generation potential with an annual average wind speed of $6-8 \mathrm{~m} / \mathrm{s}$ and up to 145 windy days per year. The majority of widely used industrial-size wind turbines operate at minimums of $3-5 \mathrm{~m} / \mathrm{s}$ wind speed (information is obtained from official web sites of Siemens and Vesta, global scale wind turbine manufacturers [31,32]). The data available at the website of the World Bank's Global Wind Atlas indicate $8 \mathrm{~m} / \mathrm{s}$ mean wind speed and $810 \mathrm{~W} / \mathrm{m}^{2}$ power density at 50-m altitude in the Absheron peninsula and its outskirts. At a 100-m height, the indicators reach $9.1 \mathrm{~m} / \mathrm{s}$ and $1026 \mathrm{~W} / \mathrm{m}^{2}$, respectively [33].

Absheron peninsula is not the only region with enough wind potential to produce power. As Figures 8 and 9 demonstrate, the Northern Sumgait and Khizi districts, KalbajarLachin and Ganja-Gazakh territories have enough wind to generate electricity. At a 100-m altitude, the mean wind speed around Khizi district is $>9 \mathrm{~m} / \mathrm{s}$, and the power density can peak $1000 \mathrm{~W} / \mathrm{m}^{2}$. In the Kalbajar-Lachin zone, results are $8 \mathrm{~m} / \mathrm{s}$ and $>700 \mathrm{~W} / \mathrm{m}^{2}$, respectively. The latter zone is mainly a mountainous territory which makes wind farming challenging. Nonetheless, the successful experience of Switzerland and technological advancements open the door for the establishment of community-sized WEPs in the mentioned area. The same can be applied in the Ganja-Gazakh economic zone where the mean wind speed is at around $5.45 \mathrm{~m} / \mathrm{s}$, perfectly suitable for utilization of mid-sized turbines. 
Table 11. Average annual wind speed (in $\mathrm{m} / \mathrm{s}$ ) and number of windy days [7].

\begin{tabular}{cccccc}
\hline Settlement & March & June & September & December & $\begin{array}{c}\text { Annual } \\
\text { Average }\end{array}$ \\
\hline Shubani & $8.7 / 14.5$ & $8.5 / 12.5$ & $8.2 / 11.5$ & $7.2 / 10$ & $8 / 145$ \\
\hline Sumgait & $7.7 / 14.6$ & $6.4 / 9.1$ & $6.9 / 10.7$ & $6.8 / 13$ & $7 / 139$ \\
\hline Puta & $7.2 / 10.8$ & $7.3 / 10.8$ & $6.4 / 9.5$ & $5.5 / 7.5$ & $6.7 / 114$ \\
\hline Pirallahi & $7.2 / 8.6$ & $6.2 / 4.2$ & $6.5 / 5.8$ & $6.6 / 6.2$ & $6.6 / 72$ \\
\hline Bina & $7.3 / 11.5$ & $6.7 / 7.5$ & $5.8 / 7$ & $5.8 / 7.8$ & $6.4 / 100$ \\
\hline Sangimughan & $6.9 / 7.3$ & $5.6 / 5.1$ & $6.9 / 6.9$ & $6.7 / 6.3$ & $6.4 / 73$ \\
\hline Baku & $6.9 / 7.5$ & $6.5 / 6.2$ & $6.2 / 4.7$ & $5.6 / 4.8$ & $6.3 / 67$ \\
\hline Chilov island & $6.6 / 5.3$ & $5.8 / 4$ & $6.3 / 4.1$ & $6.3 / 5.2$ & $6.2 / 54$ \\
\hline Oil rocks & $6.9 / 6.9$ & $5.3 / 3.3$ & $6.4 / 4$ & $6.7 / 4$ & $6.2 / 52$ \\
\hline Mardakan & $6.6 / 7.4$ & $5.8 / 4.7$ & $5.4 / 5.2$ & $5.6 / 4.6$ & $5.9 / 67$ \\
\hline Mashtaga & $6.7 / 7.9$ & $5.7 / 4.2$ & $5.3 / 4.7$ & $5.4 / 5.4$ & $5.8 / 64$ \\
\hline Davachi & $4.6 / 4.8$ & $4.6 / 4.2$ & $4.6 / 5$ & $4.1 / 3.4$ & $4.5 / 51$ \\
\hline Neftchala & $4.8 / 3.8$ & $4.4 / 2.3$ & $4.2 / 2.9$ & $3.7 / 1.9$ & $4.2 / 30$ \\
\hline Sara island & $4.4 / 4.3$ & $4.5 / 4$ & $3.9 / 3.3$ & $3.2 / 2.1$ & $4 / 36$ \\
\hline Alat & $4 / 4.1$ & $4.1 / 2.8$ & $4.2 / 3.3$ & $3.3 / 2.5$ & 3.837 \\
\hline Astara & $2.8 / 1.3$ & $2.7 / 0.5$ & $2.7 / 0.3$ & $2.7 / 1.1$ & $2.8 / 30$ \\
\hline Khachmaz & $2.4 / 0.9$ & $2.5 / 0.9$ & $2.3 / 1.2$ & $2 / 0.6$ & $2.3 / 13$ \\
\hline Guba & $1.8 / 0.8$ & $2.1 / 0.4$ & $1.9 / 0.2$ & $1.7 / 0.4$ & $1.9 / 6$ \\
\hline Lankaran & $1.7 / 0.5$ & $1.9 / 0.3$ & $1.8 / 0.2$ & $1.4 / 0.2$ & $1.8 / 3$ \\
\hline
\end{tabular}

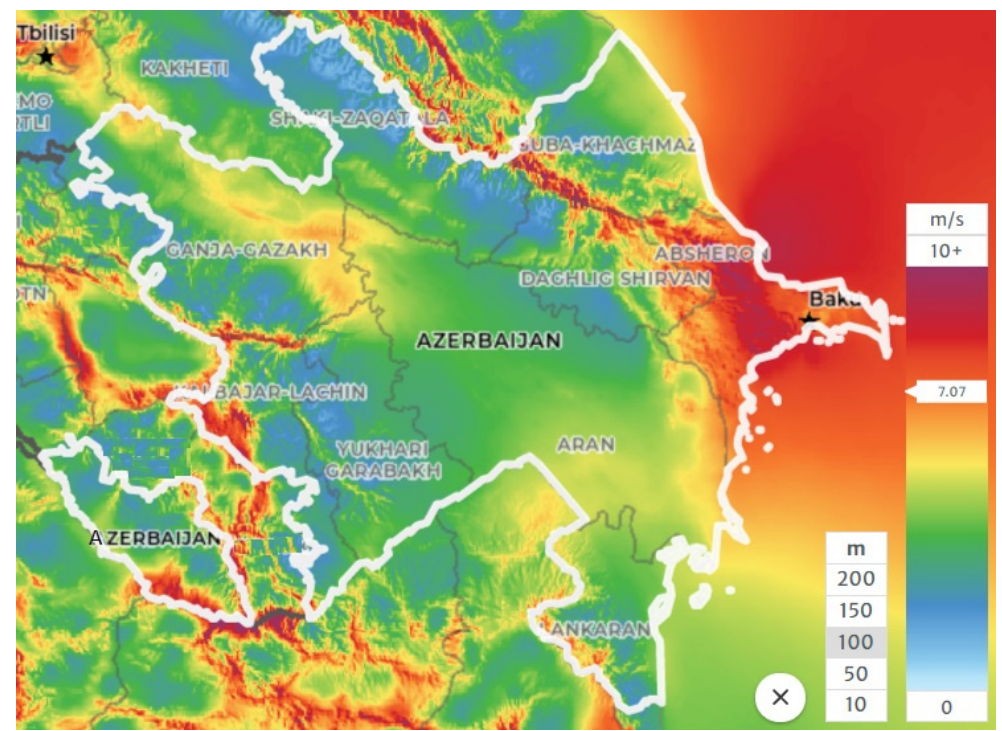

Figure 8. Mean wind speed at 100-m altitude [33]. 


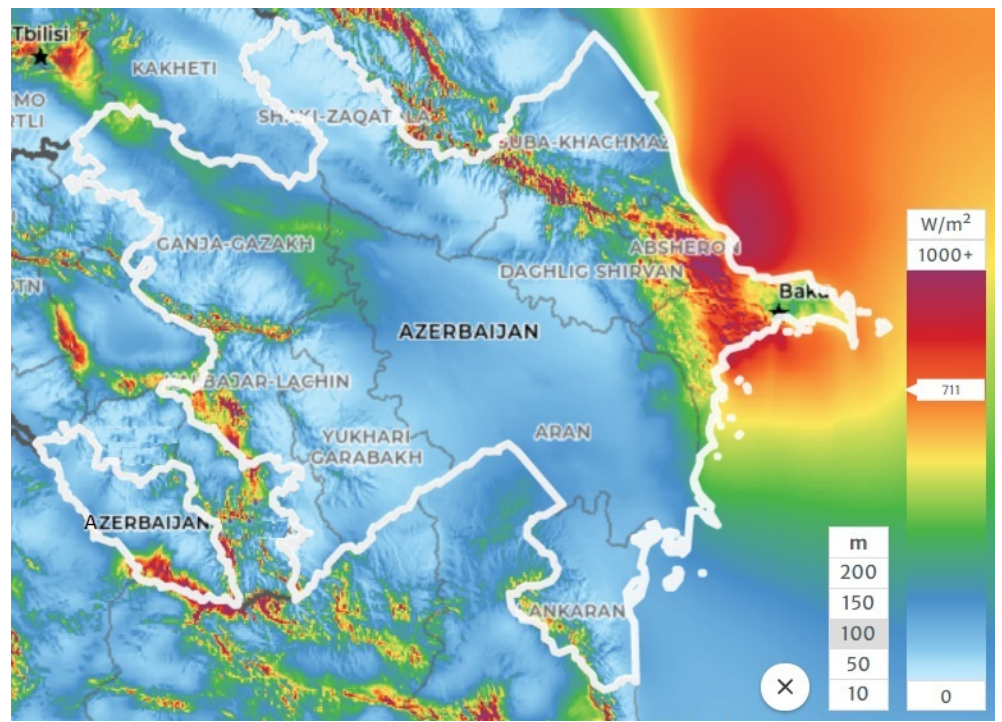

Figure 9. Wind power density at 100-m altitude [33].

The Ministry of Energy of Azerbaijan has presented five potential WEPs that could be set up with a total installed capacity of 442.5 MW (see Table 12).

Table 12. Prospective WEPs projected by the Ministry of Energy of Azerbaijan [27,34].

\begin{tabular}{ccc}
\hline Project Name & Planned Output Capacity & Estimated Generation \\
\hline Khizi 2 & 69 MW $(20$ turbines $\times 3.45 \mathrm{MW})$ & $192,000 \mathrm{MWh} /$ year \\
\hline Khizi 3 & $135.3 \mathrm{MW}(41$ turbines $\times 3.3 \mathrm{MW})$ & $414,000 \mathrm{MWh} /$ year \\
\hline Gizildash & $105 \mathrm{MW}(35$ turbines $\times 3.0 \mathrm{MW})$ & $313,670 \mathrm{MWh} /$ year \\
\hline Pirekushkul & $78 \mathrm{MW}(26$ turbines $\times 3.0 \mathrm{MW})$ & $225,000 \mathrm{MWh} /$ year \\
\hline Absheron-Garadagh & $55.2 \mathrm{MW}(16$ turbines $\times 3.45 \mathrm{MW})$ & $198,000 \mathrm{MWh} /$ year \\
\hline
\end{tabular}

Potential utilization of territories other than the Absheron peninsula for wind farming purposes was suggested by F. Mustafayev in his study (2021). Two prospective WEPs could be set up in the Kalbajar-Lachin and Ganja-Gazakh territories with a total installed capacity of 207 MW (see Table 13).

Table 13. Prospective WEPs in the Ganja-Gazakh, and Kalbajar-Lachin zones.

\begin{tabular}{ccc}
\hline Project Name & Planned Output Capacity & Annual Estimated Production \\
\hline $\begin{array}{c}\text { Ganja-Gazakh } \\
\text { (at a projected area of } \approx 700 \mathrm{ha})\end{array}$ & $138 \mathrm{MW}$ (40 Siemens SG 3.4 turbines) & $\approx 362,000 \mathrm{MWh} /$ year \\
\hline $\begin{array}{c}\text { Kalbajar-Lachin } \\
\text { (at a projected area of } \approx 350 \mathrm{ha})\end{array}$ & $69 \mathrm{MW}$ (20 Siemens SG 3.4 turbines) & $\approx 181,000 \mathrm{MWh} /$ year \\
\hline Total & $207 \mathrm{MW}$ (60 Siemens SG 3.4 turbines) & $\approx 543,000 \mathrm{MWh} /$ year \\
\hline
\end{tabular}

Source: Feyruz Mustafayev, Design of Solar Plants and Wind Farms Locations in Azerbaijan in the Perspective of Twenty Years, Working paper, 2021 [28].

The off-shore potential of the Caspian Sea is as attractive as the on-shore potential of the territories mentioned above. The World Bank study of the technical potential of the Caspian Sea indicates more than $7.5 \mathrm{~m} / \mathrm{s}$ mean wind speed in the basin around the Absheron peninsula and northern part of Azerbaijan at the depth of fewer than $50 \mathrm{~m}$ (see Figure 10) [35]. 


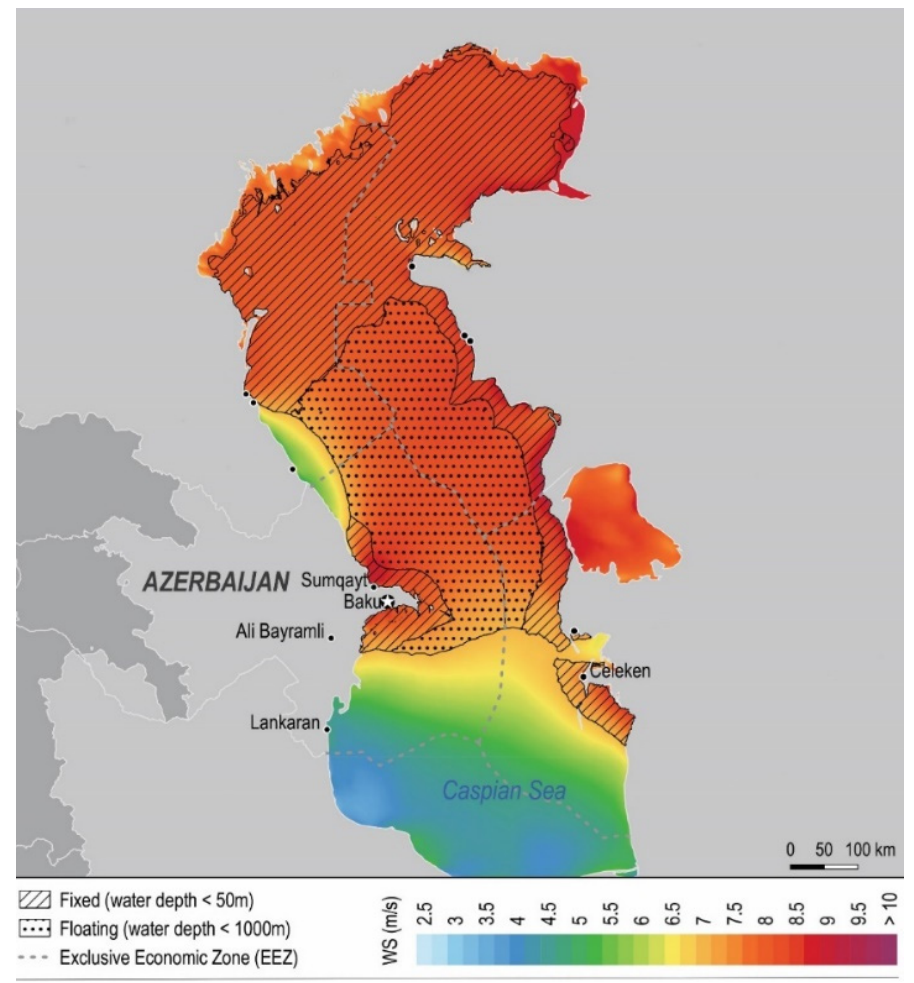

Figure 10. Wind atlas of the Caspian Sea [35].

In 2019, Florin Onea and Eugen Rusu carried out estimations to test the feasibility of wind electricity farming in the Caspian Sea, and the results were not satisfying. Based on the data obtained from the European Centre for Medium-Range Weather Forecasts and the AVISO+ (Archiving, Validation, and Interpretation of Satellite Oceanographic Data), Onea and Rusu have concluded that the only acceptable results could be achieved through the utilization of capable Siemens turbines at the 140-m altitude (results showed estimated production of $19.29 \mathrm{GW} / \mathrm{h}$ ) [36]. Back in 2004, the National Academy of Sciences of Azerbaijan drafted a project in the Caspian Sea where an output capacity of 1800 MW was envisaged to be achieved through the installation of 3000 turbines in the area of $180 \mathrm{~km}^{2}$ [37]. Nonetheless, the reliability of the mentioned study is questionable since the technological opportunities at the time were behind the current advancement.

Summing up, from a technical and organizational point of view, it looks as if locating wind farms in Azerbaijan could be easier due to the proximity to consumers and a market. The most proposed locations for WEPs are near Baku conurbation (main centers of the country) and the transfer of energy for short distances cannot be a problem. The successful realization of the Contract of the Century in petrochemical industry can be an example that Azerbaijan can be a good partner for such collaboration. The collected evidence is assessed as highly certain with low-risk of bias.

\section{Legal Framework Regulating Renewables and Incentivization}

The current legal framework regulating the energy market is mainly built with a focus on the role of the government (through public utilities) as the key actor and the other role being played by the hydrocarbon resources. Below are the five main laws which can be considered as the cornerstone of all programs and strategies adopted related to the energy industry:

1. The Law on Energy (Law 541-IQ, 1998);

2. The Law on Electrical Power (Law 459-IQ, 1998);

3. The Law on Electrical and Thermal Power Plants (Law 784-IQ, 1999); 
4. The Law on Utilization of Renewable Sources in the Electricity Production (Law 339-VIQ, 2021);

5. The Law on Efficient Use of Energy Resources and Effectiveness of Energy (Law 359-VIQ, 2021).

In 1998, the Law on Energy was adopted where special focus on the development of renewables and minimizing the carbon footprint in energy generation were set as targets to achieve. At the same time, the government was declared to be the sole grantor of special permissions and licenses to any actor who would like to be present in the energy market (Law 541-IQ, 1998). The Law on the Electrical Power adopted in 1998 was the first-ever legal act where private generators were mentioned as energy market actors, and even encouraged the liberalization of the market (Law 459-IQ, 1998). Law 459-IQ defined the following actors of the energy market:

- State utilities;

- Private generators-these actors possess rights to sell generated electricity to the state utility or the supply company (monopolized by public utilities). The excess volume of the generated electricity should be bought by state utilities;

- Energy supply companies (public utilities only);

- End consumers.

Following the Law 459-IQ, the Law on Electricity and Thermal Power Plants have reiterated the position of the state to welcome the private generators to participate in the market given they operate in their private property and can either sell the energy to public utilities or use it for private purposes only (Law 784-IQ, 1998).

In 2021, two new laws were adopted. The most important one for the development of the REI is the Law on Utilization of Renewable Sources in the Electricity Production (Law 339-VIQ). This became the very first act exclusively focusing on the renewables. The Law 339-VIQ defines roles and responsibilities of the state and generators, enlists support mechanisms to be offered, and principles of the regulation of REI.

Following the law 339-VIQ, the Law on Efficient Use of Energy Resources and Effectiveness of Energy (Law 359-VIQ) was adopted where renewable energy resources were included into the list of resources which should be stimulated in the future. Nonetheless, the law itself has a very low focus on renewable energy resources. In fact, the word "renewables" is used only twice in the document, in general lists only (Law 359-VIQ, 2021). The Law 359-VIQ has replaced the Law on the Utilization of Energy Resources (94-IQ) which had more provisions about renewables, including the idea of the establishment of a special fund to support the utilization of energy resources, including renewables.

To summarize, the fundamentals of the legal framework regulating the energy market notes the renewables as an alternative source to hydrocarbons, expresses importance to develop renewables, allows private actors to participate in the energy market, and declares the state's will to introduce special mechanisms to boost all the aforementioned. Nonetheless, the realization of all these provisions still has room to improve, e.g., very few small private actors are currently present in the energy market.

Apart from the mentioned laws, two state programs were adopted with the aim to boost developments in the renewables industry. In 2004, the State Program on Utilization of Alternative and Renewable Energy Sources in Azerbaijan was adopted which defined the assessment of the country's renewable potential, its incorporation into the energy system, development of the legal framework regulating the renewables industry, and took measures to accelerate the privatization of small-scale generation plants, including renewables as key targets among others [4]. In 2011, the government adopted the 2012-2020 State Strategy on Utilization of the Alternative and Renewable Energy Sources in Azerbaijan as another attempt to boost the REI. The third document where the development of the REI was highlighted as important and strategic came in 2014 with the 2015-2020 State Program for the Development of Industry in Azerbaijan.

Nonetheless, the REI's development in Azerbaijan has not actually accelerated until the end of the 2010s and the beginning of the 2020s. Despite a number of legal acts noting 
the importance of the renewables and liberal energy market, the situation has not changed due to a number of reasons related to energy security, abundant fossil reserves where a huge amount of investment is attracted with long-term contracts on the exploration, extraction, and utilization, less liberal nature of the market, blurry mechanisms of entering the energy market, unavailability or deficiency of publicly available information on requirements, obtaining necessary permissions and licenses to become an actor in the energy market, etc. In 2020, the Ministry of Energy has presented a developed model of the energy market with private actors being involved in generation and supply to the end-users (see Table 14).

Table 14. Target energy market model [38].

\begin{tabular}{|c|c|c|c|c|c|c|c|}
\hline & Public utilities & & & & & & Public utilities \\
\hline 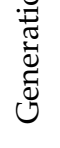 & $\begin{array}{c}\text { Private } \\
\text { companies }\end{array}$ & 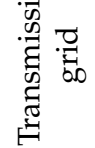 & $\begin{array}{ll}\text { 1. } & \text { Transmission } \\
\text { 2. } & \text { Dispatch } \\
\text { 3. } & \text { Market operating }\end{array}$ & 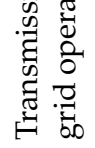 & Public utility & 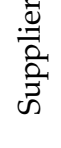 & $\begin{array}{c}\text { Private } \\
\text { companies }\end{array}$ \\
\hline
\end{tabular}

The main difference of the new model presented by the Ministry of Energy, in comparison to the earlier mentioned legal regulation, is that private companies will now be able to sell the generated electricity to consumers.

The experience of countries with successful shift paths to renewables demonstrates the importance of supporting mechanisms in attracting private investment into the energy market. This is another aspect that historically lacked in Azerbaijan, although back in the 1990s, the idea of introducing incentivizing schemes was mentioned (see laws 94-IQ, and 459-IQ). Interestingly, the Ministry of Energy has presented two different documents announcing different support mechanisms to the development of the energy market and renewables (see Table 15).

Table 15. Support mechanisms announced by the Ministry of Energy of Azerbaijan.

\begin{tabular}{ll}
\hline \multicolumn{1}{c}{ Energy Sector in Azerbaijan } & \multicolumn{1}{c}{$\begin{array}{c}\text { Names of Documents } \\
\text { Development of the Renewables in } \\
\text { Azerbaijan }\end{array}$} \\
\hline Feed-in-Tariffs & $\begin{array}{l}\text { Mechanism to offer high potential zones to private } \\
\text { investors either directly or through a selection process }\end{array}$ \\
\hline $\begin{array}{l}\text { Special mechanisms to support active } \\
\text { market actors }\end{array}$ & Feed-in-Tariffs \\
\hline Provision of subsidized loans & Special tax and customs regimes \\
\hline Research and development support & Net metering/net billing \\
\hline
\end{tabular}

Feed-in-Tariffs (FITs) are the only support mechanism widely used in countries with successful REI development. In 2018, the Council of European Energy Regulators (CEER) presented its Status Review of Renewable Support Schemes in Europe for 2016 and 2017 where the following policies were highlighted as the most commonly adopted in European countries:

- $\quad$ Feed-in-Tariffs (FITs);

- Feed-in-premiums (also referred to as FIPs);

- Tradeable green certificates; and

- Investment grants [39].

A lack of a robust legal framework is the major obstacle in the way of the development of the REI. Despite numerous documents and laws, attention to renewables has not been that much of a priority until recent years. The implementation rate of the newly proposed regulatory acts, energy market models, and supportive policies is yet to be seen. However, 
positive momentum towards the green energy adoption is in place, and the volume of efforts and resources spent in this direction is increasing. At the end of 2019, the government reported about an intensified partnership with various companies to gain experience in the development of a regular framework regulating the renewables industry. A contract was signed with Norwegian DNV Energy Advisory LTD with an aim to receive expertise on: (a) the attraction of private investment into renewables; (b) the preparation of incentivization mechanisms for private actors; (c) to achieve the increased share of renewables in electricity consumption [40]. At the same time, the Ministry of Energy announced that work is being done on the preparation of tendering mechanisms to attract private investors into the energy market [41].

Taking into account that Azerbaijan is a relatively small energy market (with around 6 thousand MW of installed energy power) and less than 2 thousand MW potential of renewable energy installations, it is questionable whether there is a need to develop sophisticated legislation similar to those in bigger countries by population, economy and with big and diversified energy sectors. For Azerbaijan, immediately, two simpler solutions come to mind. The first one is to establish a contractual basis similar to that on petrochemical industry reconstruction (Contract of the Century), which for many reasons could be considered as a perfect tool for both: assuring national energy security and development of the industry. The second solution is the creation of a simple auction framework like many countries, which assures the low cost of supplied green energy and the possibility to fulfill the project as a joint venture. According to the authors' opinion, a contractual basis can work better in the case of Azerbaijan, due to their experience in implementation of the Contract of the Century, possibilities to simplify the consortium to reduce the number of partners and building simple framing conditions which express together the national economic interests of Azerbaijan and the interests of partners involved in the project. Such a project could be implemented as a joint venture with the leading Azerbaijan energy company.

The evidences collected in the area of legal framework for renewal energy implementation are characterized by the overall assessment that they represent the early stage of development, and their functioning is not as certain as the assessment of evidence in the diagnostic part and in assessing the potential for renewable energy in Azerbaijan. This situation creates both challenges but also opportunities for the future, which can be used by the regulatory authorities.

\section{Conclusions, Recommendations and Future Research Directions}

\subsection{Conclusions}

The rationale of this review was to assess of the readiness of Azerbaijan to introduce an energy policy shift towards renewable energy with special emphasis placed on solar and wind energy. The shift to green energy production and reduction of carbon footprint in power generation is a universally accepted trend with the majority of countries reaching significant achievements, or at least submitting action plans with clear-cut targets to achieve. Azerbaijan grasped this trend in the late 2010s, although since the 1990s, numerous legal acts had provisions on renewables. Abundant fossil reserves have been a priority until recently due to a number of reasons listed below, but not limited to:

- Azerbaijan historically had a developed hydrocarbon industry, roots of which go as far back as the 19th century;

- Oil and gas resources helped attract huge investments which became a driver of the economy, especially soon after independence was gained;

- $\quad$ Abundant domestic reserves ensured energy security;

- Oil and gas became the cornerstone of foreign trade;

- Extensive resources helped Azerbaijan become an investor in foreign markets, thus enhance political and economic relations with strategically important countries.

Nonetheless, decreasing extraction levels of resources, increasing volatility of oil and gas prices, the obvious advantages of renewables over hydrocarbon resources in energy generation, and the responsibilities taken under the Paris Climate Agreement make the 
shift towards carbon-zero generation an inevitable target (Azerbaijan has signed the Paris Climate Agreement in 2016 undertaking responsibility to reduce the carbon emissions by $35 \%$ by 2030 in comparison to the 1990 /base year [42]).

The renewable potential of the country is at a high enough level to achieve a significant penetration level of green-based generation into final consumption. Assessment of the IRENA revealed especially high solar and wind potential (see Table 8) which has become the focal point of the government if only to analyze recent investments and announced projects. Publicly available wind and solar maps portray favorable conditions to set up industrialsize solar and wind plants in at least 2-3 different zones. At the same time, vast territories are suitable for private to small-scaled generation or establishment of green communities.

The energy market of the country is currently controlled by public entities. The share of the private generation is close to zero with very few private actors participating in the market. Nonetheless, the existing legal framework and proposed ideas lay a solid foundation to increase the share of private generation. Liberalization of the market, incentivization of private investments are set as a priority in a number of documents adopted over the last 2 years.

The current legal framework has room for improvement in terms of regulating the REI. The negative impact of less efficient legal regulation had been one of the major factors obscuring the development of the REI until 2021. The Ministry of Energy has presented several projects announcing incentivization schemes and submitted draft proposals for a new law to regulate energy efficiency and effectiveness for revision of the government. Taking all those aspects into account, it can be admitted that Azerbaijan is ready to introduce the main shift in the energy policy towards renewable energy sources. Below is the brief SWOT analysis in the Table 16 to indicate internal and external factors as well as risks that could impact transition to renewable sources.

Integration of renewables into the energy system is an ongoing process even in countries with very rich experience in terms of generating fossil-free energy. The majority of countries are seeking the support of expert organizations in drafting a strategy, program, or action plan to smoothly integrate renewables into the existing energy system. Not surprisingly, one of the leading actors in this market is IRENA. As per the 2019 report of IRENA, the organization has provided assistance to Japan in recent years and continues active work with G20 countries in this direction [43]. Azerbaijan can also work with IRENA to develop a strategy to get prepared for a well-planned integration of renewables into the existing energy system.

Integration of variable renewable energy (VRE) (variable renewable energy (VRE): "electricity generation technologies whose primary energy source varies over time and cannot easily be stored. VRE sources include solar, wind, ocean, and some hydropower generation technologies." [44]) into the energy system requires consideration of several factors which are:

- Integration to the grid;

- Balancing supply and demand;

- Creating storage capacity;

- Establishing the necessary legal base.

All the above-mentioned factors should be analyzed carefully and technical issues must be addressed before any major transition to renewables. 
Table 16. SWOT analysis for switching to REI in Azerbaijan.

\begin{tabular}{|c|c|}
\hline Strengths & $\begin{array}{l}\text { - internal demand for electricity is growing as the economy develops; } \\
\text { high natural potentials for the development of renewable energies in Azerbaijan, with growing evidence, projects, } \\
\text { plans and maps; } \\
\text { - LCOE of renewable sources, in particular, that of solar power is decreasing (see Table 1); } \\
\text { - } \quad \text { the government has the will to support environmentally friendly green energy; } \\
\text { commitments to climate change-related international pacts drive the country to invest in carbon-free } \\
\text { energy sources; } \\
\text { Azerbaijan has an excellent reputation as a cooperative partner in energy investments (example of the "contract of } \\
\text { the century"). }\end{array}$ \\
\hline Weaknesses & $\begin{array}{l}\text { - Azerbaijan is rich in fossil fuels and these sources can provide energy security of the country for the subsequent } \\
\text { decades and relax pressure for a change; } \\
\text { moderate social consciousness of the necessity of change in energy policy towards renewables; } \\
\text { - low to moderate technical, legislative and organizational expertise of national bodies in the implementation of } \\
\text { renewable energies in Azerbaijan. }\end{array}$ \\
\hline Opportunities & $\begin{array}{l}\text { - the wide number of international best practices, examples of expertise, legislative solutions, and case studies on } \\
\text { successful changes of energy policies towards REI by different countries-to be used in Azerbaijan; } \\
\text { the growing interest of international investors interested in investing in REI in Azerbaijan-evidenced by the } \\
\text { growing number of business and official contacts in Azerbaijan; } \\
\text { new laws and regulations are introduced to liberalize the energy market in Azerbaijan and attract private } \\
\text { renewable energy producers based on international best practices; } \\
\text { the ability to achieve substantial improvements in REI by a limited number of new REI projects. }\end{array}$ \\
\hline Threats & $\begin{array}{l}\text { - growing criticism towards REI due to the lack of storage capacity for electricity produced from renewables; } \\
\text { growing criticism towards REI due to the daily and seasonal fluctuations in the production of solar and wind } \\
\text { power make these sources less sustainable; } \\
\text { changes on international credit and investment markets which will make the new investment harder (such as } \\
\text { growing inflation). }\end{array}$ \\
\hline
\end{tabular}

\subsection{Recommendations}

Below, the authors form key recommendations that could help Azerbaijan with a transition to carbon-zero energy generation. The recommendations correspond with revealed gaps in analysis of energy policy of Azerbaijan.

1. The legal framework should be further developed to include more specific details on the liberalization of the market, support mechanisms and the role of private actors or alternatively simple rules for contractual renewals big project should be established (resembling the Contract of the Century) (gap: imprecise legal framework);

2. The energy market should be liberalized and supported with easy access to relevant information for all participants (gap: a limited number of companies involved in energy policy realization);

3. Blurry and vague requirements to obtain contracts, permissions and licenses should be improved and made publicly available (gap: imprecise legal framework);

4. Supportive policies should be applied to stimulate the inflow of private capital into the energy industry (gap: too few companies involved in energy policy realization);

5. Efforts should be put in place to promote and support private and community-scale green energy generation (gap: too few companies involved in energy policy realization);

6. Public awareness of the benefits of the renewable resource should be increased and backed with widely accessible information (gap: insufficient information on renewable energy potentials and opportunities);

7. Research and development of the renewables industry, including collection of proper data, should be promoted and supported by the government (gap: insufficient information on renewable energy potentials and opportunities);

8. Experience of successful countries in terms of REI development should be assessed and considered as domestic expertise on green resources is low (gap: insufficient information on the best practices fitted to the size and characteristics of Azerbaijan available). 


\subsection{Future Research Directions}

The further research in transformation of energy policy of Azerbaijan towards renewable energy could also address social issues. The advantages of the REI are not limited to the energy industry. Its positive impact on economic growth, social welfare, and employment has already been studied and proved by many individuals and organizations. Measuring the Economics report presented by the IRENA in 2016 and Renewable Energy Development as a Driver of Economic Growth: Evidence from Multivariate Panel Data Analysis (2019) study by Nadia Singh, Richard Nyuur, and Ben Richmond has proved a significant positive correlation between the development of the REI and the increase in GDP $[45,46]$. The latter study conducted among the OECD countries revealed $57 \%$ potential of GDP growth with successful REI development, though the scale of interdependency between the two variables differs across contexts. The IRENA's Measuring the Economics report has also proved the positive impact of the REI on social welfare through economic, social, and environmental dimensions. The "How Clean-Energy Policies Can Fight Poverty and Raise Living Standards in the United States" study presented by Robert Pollin et al., and Veronika Czako's "Employment in the Energy Sector: Status Report 2020" revealed REI's positive impact on employment [47,48].

It is quite clear that economic development is near impossible without renewable energy technologies, however, for technology to be ubiquitous, there needs to be a reliable and cheap source of power (1) as noted by the report of the G8 Renewable Energy Task Force [49] "no country has been able to develop its economy beyond subsistence level without access to more than a minimum level of modern energy "; (2) additionally, the report states that "Economies can only grow if they are not threatened by environmental catastrophe or social unrest"; (3) this again strengthens the case for not only affordable energy but sustainable and renewable energy choices.

As displayed in the Table 17, renewable energy sectors can create more job opportunities on the labor market. Poverty reduction through sustainable job development, improved health through a cleaner environment, and low-cost energy for consumers seems to be a win-win.

Table 17. Employment in different energy sectors (jobs per MW) [50].

\begin{tabular}{lccc}
\hline \multicolumn{1}{c}{ Sector } & $\begin{array}{c}\text { Construction \& } \\
\text { Installation }\end{array}$ & Manufacturing & $\begin{array}{c}\text { Operation \& } \\
\text { Maintenance }\end{array}$ \\
\hline Solar PV & 13.0 & 6.70 & 0.70 \\
\hline Wind onshore & 3.20 & 4.70 & 0.30 \\
\hline Wind offshore & 8.00 & 15.6 & 0.20 \\
\hline Hydro-large & 7.40 & 3.50 & 0.20 \\
\hline Oil and gas & 1.30 & 0.93 & 0.14 \\
\hline Coal & 11.2 & 5.40 & 0.14 \\
\hline
\end{tabular}

The benefits of green energy are obvious, and they have the potential to support the social development of the country. Azerbaijan possesses enough renewable resources to significantly develop the renewables industry. The deficiencies are the lack of a strong legal framework and expertise on the matter. The upcoming years will witness rapid developments in the renewables industry, as the President of the Republic of Azerbaijan Ilham Aliyev proposed "clean environment and 'green growth' country" to be one of five strategic objectives to be reached by 2030 [51].

Growing prices for natural gas will probably have the long run tendency toward stability, due to the climate policy of the EU and other main players in the energy market. The high cost of natural gas and the high costs of its transportation may facilitate the production of chemicals (such as fertilizers) and other energy intensive products, closer to energy sources. According to the authors, it is a role for natural gas producers, such as Azerbaijan, to attract foreign direct investment to producers' countries in order to 
conduct, in diversified joint venture forms, chemical production. This will lower the cost of production, costs of transportation and overall costs of production of energy intensive products. Thus, supporting conversion towards a green economy. The inflow of FDI can facilitate the social and economic development of Azerbaijan.

Author Contributions: Conceptualization, F.M. and P.K.; methodology, P.K.; analysis and investigation, F.M. and P.K.; writing-original draft preparation, F.M. and P.K.; writing-review and editing, C.O.; supervision, P.K.; project administration, C.O.; funding acquisition, P.K. All authors have read and agreed to the published version of the manuscript.

Funding: This research was funded by University of Gdansk.

Data Availability Statement: Links are provided in the references.

Conflicts of Interest: The authors declare no conflict of interest.

\section{References}

1. International Renewable Energy Agency. Renewable Power Generation Costs in 2020; Abu Dhabi, United Arab Emirates. 2021. Available online: https:/ / www.irena.org/publications/2021/Jun/Renewable-Power-Costs-in-2020 (accessed on 12 July 2021).

2. International Energy Agency. Global Energy Review 2021; IEA: Paris, France, 2021.

3. BP. Statistical Review of World Energy 2020, BP 69th Edition. Available online: https://www.bp.com/content/dam/bp/businesssites/en/global/corporate/pdfs/energy-economics/statistical-review/bp-stats-review-2020-full-report.pdf (accessed on 12 July 2021).

4. The State Program on Use of Alternative and Renewable Energy Sources in Azerbaijan. 2004. Available online: http:// www.inogate.org/documents/AZ_2004_10_21_State_Program_on_Renewable_Energy_of_Azerbaijan_Republic.pdf (accessed on 15 July 2021).

5. Higgins, J.P.T.; Thomas, J.; Chandler, J.; Cumpston, M.; Li, T.; Page, M.J.; Welch, V.A. Cochrane Handbook for Systematic Reviews of Interventions, 2nd ed.; John Wiley \& Sons: Chichester, UK, 2019.

6. Schünemann, H.; Brożek, J.; Guyatt, G.; Oxman, A. GRADE Handbook. 2013. Available online: https://gdt.gradepro.org/app/ handbook/handbook.html (accessed on 28 December 2021).

7. Nijat, I. Azerbaijan's Wind Energy Potential and its Utilization Perspectives; Published by academia.edu. 2014. Available online: https:/ / www.academia.edu / 19045528/Az\%C9\%99rbaycan\%C4\%B1n_K\%C3\%BCl\%C9\%99k_Enerji_Potensial\%C4\%B1_v\%C9 \%99_Onlardan_\%C4\%B0stifad\%C9\%99_\%C4\%B0mkanlar\%C4\%B1_Wind_Energy_Potential_of_Azerbaijan_and_Availability_ of_Its_Using (accessed on 15 July 2021).

8. LatLong Latitude and Longitude Finder. 2021. Available online: https://www.latlong.net/ (accessed on 10 July 2021).

9. The European Union. Living in the EU. 2019. Available online: https:// europa.eu/european-union/about-eu/figures/living_en\# tab-0-1 (accessed on 10 July 2021).

10. International Renewable Energy Agency. Renewable Energy Capacity Statistics; International Renewable Energy Agency: Abu Dhabi, United Arab Emirates, 2020.

11. Nicolas, N. Top Ten Countries with the Highest Proportion of Renewable Energy. 2020. Available online: https://www.smart-energy. $\mathrm{com} /$ renewable-energy/top-ten-countries-with-the-highest-proportion-of-renewable-energy/ (accessed on 28 December 2021).

12. Miryusif, M. Azerbaijan's Oil History; Azerbaijan International: Baku, Azerbaijan, 2002.

13. Vassiliou, M.S. Historical Dictionary of the Petroleum Industry; Scarecrow Press Inc.: Lanham, MD, USA, 2009.

14. Ibrahimov, M.I.M. Pre-Revolutionary History of Azerbaijani Oil; Elm: Baku, Azerbaijan, 1991.

15. State Statistics Committee of the Republic of Azerbaijan. Production of Electricity. 2021. Available online: https://www.stat.gov. az/source/balance_fuel/?lang=en (accessed on 25 July 2021).

16. Sagheb, M.J.N. Azerbaijan's 'Contract of the Century' Finally Signed with Western Oil Consortium; Azerbaijan International: Baku, Azerbaijan, 1994.

17. State Statistics Committee of the Republic of Azerbaijan. System of National Accounts and Balance of Payments. 2021. Available online: https:/ / www.stat.gov.az/source/system_nat_accounts/?lang=en (accessed on 28 July 2021).

18. The World Bank. Inflation, Consumer Prices, Azerbaijan. 2021. Available online: https://data.worldbank.org/indicator/FP.CPI TOTL.ZG? end=2020\&locations=AZ\&start=1992\&view=chart (accessed on 14 September 2021).

19. Yusifov, J. Overview of the Renewable Energy Developments in Azerbaijan. 2018. Available online: https://www.irena.org/-/ media/Files/IRENA/Agency / Events/2018/Oct/2-Azerbaijan-country-presentation--Jabir-Yusifov.pdf?la=en\&hash=385692 54F73994725DEBDC2B96C9FF6C2BEC48D5 (accessed on 28 July 2021).

20. Ministry of Energy of the Republic of Azerbaijan. Utilization of Renewable Energy Resources in Azerbaijan. 2020. Available online: https:/ / minenergy.gov.az/az/alternativ-ve-berpa-olunan-enerji/azerbaycanda-berpa-olunan-enerji-menbelerindenistifade (accessed on 2 August 2021).

21. Azerbaijan State Agency for the Alternative and Renewable Energy Sources. History. 2018. Available online: http://www.area. gov.az/page/41 (accessed on 4 August 2021). 
22. State Statistics Committee of the Republic of Azerbaijan. Energy Balance of Azerbaijan. 2020. Available online: https:/ /www.stat. gov.az/source/balance_fuel/?lang=en (accessed on 4 August 2021).

23. The International Renewable Energy Agency. Renewables Readiness Assessment: Republic of Azerbaijan; International Renewable Energy Agency: Abu Dhabi, United Arab Emirates, 2019.

24. Ministry of Energy of the Republic of Azerbaijan. Perspectives of Renewable and Alternative Energy Sources in Azerbaijan; Ministry of Energy of the Republic of Azerbaijan: Baku, Azerbaijan, 2014.

25. Zhang, T. What's a Good Value for kWh/kWp? An Overview of Specific Yield. 2017. Available online: https://www. solarpowerworldonline.com/2017/08/specific-yield-overview/\#: \{\}:text=Specific\%20yield\%20(or\%20simply\%20\%E2\%80\% 9Cyield, Location (accessed on 16 September 2021).

26. The World Bank Group Global Solar Atlas. Global Solar Atlas. 2021. Available online: http://www.globalsolaratlas.info/ (accessed on 12 August 2021).

27. The Ministry of Energy of the Republic of Azerbaijan. Development of the Renewable Industry in Azerbaijan; Ministry of Energy of the Republic of Azerbaijan: Baku, Azerbaijan, 2020.

28. Mustafayev, F. The Potential Role of Renewable Energy in Providing Energy Security of Azerbaijan. Unpublished. Ph.D. Thesis, University of Gdansk, Sopot, Poland, 2021.

29. Energy Solutions. How Much Energy Do Solar Panels Produce for Your Home? 2020. Available online: https://www yesenergysolutions.co.uk/advice/how-much-energy-solar-panels-produce-home\#: \{\}:text=Solar\%20panel\%20output\%20 per $\% 20$ square $\% 20$ metre\&text=rated $\% 20$ to $\% 20$ produce $\% 20$ roughly $\% 20265$,of $\% 20$ power $\% 20$ (in $\% 20$ ideal $\% 20$ conditions) (accessed on 2 September 2021).

30. Sharma, G. Production Cost of Renewable Energy Now 'Lower' Than Fossil Fuels. 2018. Available online: https://www.forbes. com/sites/gauravsharma/2018/04/24/production-cost-of-renewable-energy-now-lower-than-fossil-fuels/\#23914695379c (accessed on 2 September 2021).

31. Vestas, V117-3.45 MW ${ }^{\circledR}$ at a Glance. 2021. Available online: https://www.vestas.com/en/products/4-mw-platform/v117-3_45_ mw\#!at-a-glance (accessed on 22 September 2021).

32. Gamesa, S. Onshore Wind Turbines. 2021. Available online: https://www.siemensgamesa.com/en-int/products-and-services/ onshore/wind-turbine-sg-3-4-145 (accessed on 22 September 2021).

33. The World Bank Group Global Wind Atlas. Global Wind Atlas. 2021. Available online: http://www.globalwindatlas.info/ (accessed on 3 September 2021).

34. APA Economics. Two WEPs to Be Constructed in Khizi with Total Output Capacity of 204 MW. 2019. Available online: https:/ / banker.az/xizida-umumi-gucu-204-mvt-olan-iki-kul\%C9\%99k-enerjisi-stansiyasi-tikil\%C9\%99c\%C9\%99k/ (accessed on 3 September 2021).

35. The World Bank. Offshore Wind Technical Potential in the Caspian Sea. 2020. Available online: https://documents1 .worldbank.org/curated/en/802421586850648405/pdf/Technical-Potential-for-Offshore-Wind-in-Caspian-Sea-Map.pdf (accessed on 5 September 2021).

36. Onea, F.; Rusu, E. An Assessment of Wind Energy Potential in the Caspian Sea. Energies 2019, 12, 2525. [CrossRef]

37. The National Academy of Sciences of Azerbaijan. Development Perspectives of Alternative Energy in Azerbaijan; The National Academy of Sciences of Azerbaijan: Baku, Azerbaijan, 2004.

38. Ministry of Energy of the Republic of Azerbaijan. Energy Sector in Azerbaijan; Ministry of Energy of the Republic of Azerbaijan: Baku, Azerbaijan, 2020.

39. Council of European Energy Regulators. Status Review of Renewable Support Schemes in Europe for 2016 and 2017. 2018. Available online: https://www.ceer.eu/documents/104400/-/-/80ff3127-8328-52c3-4d01-0acbdb2d3bed (accessed on 8 September 2021).

40. APA. Azerbaijan Develops Renewable Energy Industry. 2019. Available online: https://apa.az/az/senaye-ve-energetika/ azerbaycan-berpa-olunan-enerji-menbelerinden-istifadesi-sahesinde-isleri-genislendirir-541364 (accessed on 8 September 2021).

41. Ismayilov, E. Tendering Mechanisms for Alternative Energy Industry to Be Prepared by the End of This Year. 2019. Available online: https:/ / apa.az/az/xeber/senaye-ve-energetika/aera-azerbaycanda-alternativ-enerji-sahesinde-herraclarin-kecirilmesiqaydalari-bu-il-hazir-olacaq-559496 (accessed on 9 September 2021).

42. The United Nations Framework Convention on Climate Change (UNFCCC). Intended Nationally Determined Contribution (INDC) of the Republic of Azerbaijan. 2015. Available online: https://www4.unfccc.int/sites/ndcstaging/PublishedDocuments/ AzerbaijanFirst/INDCAzerbaijan.pdf (accessed on 22 September 2021).

43. International Renewable Energy Agency. Solutions to Integrate High Shares of Variable Renewable Energy; International Renewable Energy Agency: Abu Dhabi, United Arab Emirates, 2019.

44. Leisch, J.C.J. Integrating Variable Renewable Energy into the Grid: Key Issues; National Renewable Energy Laboratory (NREL): Golden, CO, USA, 2015.

45. IRENA. Measuring the Economics; IRENA: Abu Dhabi, United Arab Emirates, 2016.

46. Singh, N.; Nyuur, R.; Richmond, B. Renewable Energy Development as a Driver of Economic Growth: Evidence from Multivariate Panel Data Analysis. Sustainability 2019, 11, 2418. [CrossRef]

47. Czako, V. Employment in the Energy Sector; EUR 30186 EN; Publications Office of the European Union: Luxembourg, 2020; ISBN 978-92-76-18206-1. JRC120302. [CrossRef] 
48. Pollin, R.; Wicks-Lim, J.; Peltier, H. Green Prosperity: How Clean-Energy Policies Can Fight Poverty and Raise Living Standards in the United States; Political Economy Research Institute, University of Massachusetts at Amherst: Amherst, MA, USA, 2009.

49. G8 Renewable Energy Task Force. Chairmen's Report; Okinawa Summit Communiqué: Nago, Japan, 2001.

50. Rutovitz, J.; Dominish, E.; Downes, J. Calculating Global Energy Sector Jobs: 2015 Methodology Update. 2015. Referenced by Czako, V., Employment in the Energy Sector; EUR 30186 EN; Publications Office of the European Union: Luxembourg, 2020.

51. The Government of the Republic of Azerbaijan. Azerbaijan 2030: National Priorities on the Socio-Economic Development; The Government of the Republic of Azerbaijan: Baku, Azerbaijan, 2021. 